\title{
Cattle Herd Dynamics of Gaushalas (Cow-shelter) in Karnataka State
}

\author{
Kalyan Mandi ${ }^{1 *}$, S. Subash ${ }^{1}$, Subrata Koloi ${ }^{2}$ and Narendra Pratap Singh ${ }^{2}$ \\ ${ }^{1}$ Dairy Extension Section, Southern Regional Station, ICAR-National Dairy Research \\ Institute, Bengaluru-560030, India \\ ${ }^{2}$ Department of Animal Genetics and Breeding, ICAR-National Dairy Research Institute, \\ Karnal-132001, Haryana, India \\ *Corresponding author
}

\section{A B S T R A C T}

\section{Keywords}

Gaushalas, Cattle,

Herd dynamics

Article Info

Accepted:

07 November 2019

Available Online:

10 December 2019
Gaushalas play a vital role in safeguarding the cattle wealth of our country. It is primarily occupied with providing shelter to cows and caters mostly the needs of nonlactating, weak, unproductive and stray cattle. This paper describes cattle herd structure and herd dynamics from a data set of 40 gaushalas selected form Karnataka state based on certain criteria. These gaushalas, an important source of indigenous germplasm, were maintaining more than 6640 heads of cattle. Herd structure of these gaushalas indicated that about 25.00 percent of the gaushalas possessed small herd size (below 50 cattle) and 30.00 percent with large herd size (above 150 cattle) followed by 45.00 percent medium herd size (between 51-150 cattle). Majority of the gaushalas comprised of more than 90.00 percent of indigenous cattle and around 5.00 percent of crossbred cattle. The total inflow of cattle due to cattle left by owners/donated, stray cattle brought and purchased by gaushala was 37, 150 and 350 in small, medium and large sized gaushalas, respectively. Whereas, in case of outflow of cattle due to death/mortality, selling and donation was 26,69 and 98 in small, medium and large sized gaushalas, respectively. The study will be helpful in identifying gaushalas as conservation centre and formulating conservation strategies for improvement of cattle genetic resources.

\section{Introduction}

Gaushala' means an institution established for the purpose of keeping, breeding, rearing and maintaining cattle for the purpose of reception, protection and treatment of infirm, aged or diseased cattle. It is primarily focused on providing shelter to cows and caters mostly to the needs of non-lactating, weak, unproductive, and stray cattle (Yadav, 2007). As per the $19^{\text {th }}$ Livestock Census (2012), India is having about 190 million cattle population, $79 \%$ of which are indigenous and the rest $21 \%$ constituted as crossbred/exotic. But, the last half decade (2012-19) has seen decline in the total indigenous cattle population to a tune of 
8.94 percent. The major factors for decrease in cattle population are attributed to uneconomical returns due to low productivity and replacement of draft power in agriculture by mechanization. As a result, particularly unproductive, old and stray cattle find shelter in the gaushalas instead of individual households. Out of about 4500 gaushalas in India which largely serves the indigenous cattle population, approximately 1850 gaushalas are registered under Animal Welfare Board of India (AWBI).

Cattle herd dynamics gives us an idea of regular inflow and outflow of cattle herd in gaushalas. Herd dynamics and performance monitoring has increasingly gained interest in recent years for livestock production system research studies, not only as a tool for system description and diagnosis of constraints, but also as a method for evaluating impacts of a livestock development project. Long term monitoring of animal performances at the farm or village level is being widely utilized by the International Livestock Center for Africa (Wilson, 1983; Wilson, 1986; Agyemang et al., 1991; Little et al., 1994). Yadav (2009) revealed from the data set of 105 gaushalas selected from Haryana state that the average inflow and outflow of cattle was 245 and 168 heads per gaushala respectively. On an average gaushalas received every year about 153 animals from owners/general public, 36 bought by the gaushala management, 26 by district administration and 27 recovered by police. Very few animals (about 2 animals/ gaushala/year) were purchased by the Gaushala management. Disposal of animals from these gaushalas was very less mainly due to deaths and selling (about 100 and 49 respectively). A few animals (about 18-19 per gaushala), mainly male calves, were also donated to other gaushalas, village panchayats and genuine farmers. Similarly, Sissokho (1998) revealed from the study in Kolda Region (Southern Senegal) that sales were the most single important means of disposal of animals, accounting for $41.10 \%$ of all exits. Deaths were also an important cause for animal losses, accounting for $27.30 \%$ of total exits from the herds, while other animal losses such as accidents, thefts or predations represented only $7.30 \%$ of total exits. Animal slaughter, which accounted only for $5.10 \%$ of total exits, was a minor avenue of animal disposals. Animal exchanges, transfers and other social transactions such as: given as gifts, dowry or inheritance jointly accounted for $19.20 \%$ of all exits in an organized farm. Therefore, herd structure and herd dynamics plays important role in livestock breeding programmes. Information on availability and exchange of breeding individuals among gaushalas, ages of breeding males and females, and breeding structure (number of breeding females/male) are essential for planning and executing an improvement programme. The aim of this paper is to report on herd structure and herd dynamics of cattle in gaushalas of Karnataka.

\section{Materials and Methods}

The study was conducted in Karnataka State during the year 2017-18 in forty (40) gaushalas, selected randomly out of total eighty (80) registered gaushalas present throughout the State. The forty selected gaushalas were further categorized as small (12), medium (18) and large sized (10) gaushalas based on the herd size i.e. small (below 50), medium (51-150) and large (above 150) animals respectively. The primary data on breed-wise and category wise cattle population were collected from the concerned individuals/stakeholders involved in maintaining the gaushalas through welldeveloped pre-tested structured questionnaire. Cattle herd dynamics was operationalised as the total inflow and outflow of cattle in the gaushalas observed during the period of study (2017-18). The inflow variables comprised of 
cattle donated or abandoned by the owners, stray cattle brought and cattle purchased by the gaushala management. The outflow variables were cattle sold, donated and dead. Herd size was operationalised as the total number of cattle heads owned by the gaushalas at the time of investigation. The gaushalas were classified into small, medium and large size based on the herd size on the basis of mean and standard deviation.

\section{Results and Discussion}

\section{Herd structure in gaushalas}

Results presented in Table 1 from the sample of forty gaushalas comprised a total herd size of 6640 cattle was categorized into small, medium and large sized gaushalas. Based on the herd size further it was observed that, in all the gaushalas more than 95.00 percent of the herd composition was indigenous cattle followed by a meager 5.00 percent of crossbred. Among the indigenous cattle maintained in the gaushalas, most of them were old and unproductive cattle in small $(32.00 \%)$, medium $(45.00 \%)$ and large sized gaushalas $(37.00 \%)$. A notable percentage $(16.00 \%)$ of the indigenous cattle were found to be 'in milk' population in all the gaushalas whereas, among the crossbred cattle the 'in milk' population were composed of 52.00 percent, 45.00 percent and 37.00 percent in small, large and medium sized gaushalas respectively.

It is noteworthy to mention that, majority $(95.00 \%)$ of the gaushalas comprised of indigenous cattle in general and among them most of them were found to be unproductive and old which could be related to their primary objective to serve the old, infirm and unproductive cattle. It was also found that the percentage share of milch cattle in indigenous cattle was less than that of the crossbred which could be attributed to less milk productivity in indigenous milk as most of the gaushalas maintained old, stray and unproductive cattle. The findings of the present study are in line with the findings of Yadav and Vij (2010) who revealed in his study on gaushalas in Haryana State that majority $(67.00 \%)$ of the cattle maintained were in dry stage followed by 6.00 percent in milking stage. Kumar et al., (2009) also reported that almost all gaushalas in Jind district of Haryana State comprised of indigenous cattle breeds compared to crossbred.

Data presented in Table 2 indicated that a significant percent $(45.00 \%)$ of the gaushalas possessed medium herd size (between 51 to 150 nos. cattle), followed by a considerable 30.00 percent of small herd size(up to 50 nos.) and one-fourth $(25.00 \%)$ possessed larger herd size (more than 150 cattle). Thus, it can be inferred from the study that majority of the gaushalas maintained small to medium herd size.

\section{Cattle herd dynamics in gaushalas}

It was observed from the Table 3and Fig 1 that there was regular inflow and outflow of cattle in all types of gaushalas. In the case of inflow of cattle in small $(45.00 \%)$, medium $(42.00 \%)$ and large sized gaushalas $(40.00 \%)$ comprised of 'cattle abandoned by owners/donated'. In case of 'stray cattle brought by Gaushala management' around 37.00 percent, 33.00 percent and 34.00 percent belonged to small, medium and large sized gaushalas, respectively, whereas remaining inflow in case of small(18.00\%), medium(25.00\%) and large $(26.00 \%)$ were due to cattle 'purchased by gaushala management'. In the case of outflow of cattle in gaushalas, the percentage of cattle 'donated' were $(58.00 \%),(51.00 \%)$ and $(82.00 \%)$ in small, medium and large sized gaushalas respectively. 
Table.1 Herd composition in gaushalas

\begin{tabular}{|c|c|c|c|c|c|c|c|c|c|c|c|c|c|}
\hline \multirow{3}{*}{$\begin{array}{l}\text { Sl. } \\
\text { No }\end{array}$} & \multirow[t]{3}{*}{ Category } & \multicolumn{4}{|c|}{ Small } & \multicolumn{4}{|c|}{ Medium } & \multicolumn{4}{|c|}{ Large } \\
\hline & & \multicolumn{2}{|c|}{ Indigenous } & \multicolumn{2}{|c|}{ Crossbred } & \multicolumn{2}{|c|}{ Indigenous } & \multicolumn{2}{|c|}{ Crossbred } & \multicolumn{2}{|c|}{ Indigenous } & \multicolumn{2}{|c|}{ Crossbred } \\
\hline & & Freq & $\%$ & Freq & $\%$ & Freq & $\%$ & Freq & $\%$ & Freq & $\%$ & Freq & $\%$ \\
\hline 1 & In Milk & 100 & 16 & 15 & 52 & 358 & 15 & 45 & 37 & 500 & 16 & 80 & 45 \\
\hline 2 & Dry & 120 & 19 & 10 & 34 & 400 & 16 & 25 & 20 & 750 & 23 & 25 & 14 \\
\hline 3 & Calves & 85 & 14 & 4 & 14 & 190 & 8 & 10 & 8 & 275 & 9 & 11 & 6 \\
\hline 4 & Heifer & 80 & 13 & 0 & 0 & 240 & 10 & 0 & 0 & 350 & 11 & 0 & 0 \\
\hline 5 & $\begin{array}{c}\text { Bull// } \\
\text { Bullock }\end{array}$ & 35 & 6 & 0 & 0 & 165 & 7 & 2 & 2 & 150 & 5 & 8 & 4 \\
\hline \multirow[t]{3}{*}{6} & $\begin{array}{c}\text { Old/ } \\
\text { Unproductive }\end{array}$ & 200 & 32 & 0 & 0 & 1112 & 45 & 40 & 33 & 1200 & 37 & 55 & 31 \\
\hline & Total & 620 & 100 & 29 & 100 & 2465 & 100 & 122 & 100 & 3225 & 100 & 179 & 100 \\
\hline & Total Percent & 96.00 & - & 4.00 & - & 95.00 & - & 5.00 & - & 95.00 & - & 5.00 & - \\
\hline
\end{tabular}

Table.2 Distribution of gaushalas based on herd size

$(n=40)$

\begin{tabular}{|c|c|c|c|}
\hline Sl.No. & Category & Frequency & Percentage \\
\hline $\mathbf{1}$ & Small (upto50) & 12 & 30 \\
\hline $\mathbf{2}$ & Medium (51-150) & 18 & 45 \\
\hline $\mathbf{3}$ & Large (above150) & 10 & 25 \\
\hline & Total & $\mathbf{4 0}$ & $\mathbf{1 0 0}$ \\
\hline
\end{tabular}

Table.3 Distribution of inflow and outflow of cattle in gaushalas

\begin{tabular}{|c|c|c|c|c|c|c|c|}
\hline & & & & INFLO & $\mathrm{OF} \mathrm{CA}^{7}$ & LE & \\
\hline Sl. & Particulars & Sm & & Med & & Lar & \\
\hline No. & & Frequency & Percent & Frequency & Percent & Frequency & Percent \\
\hline 1 & $\begin{array}{l}\text { Cattle abandoned by } \\
\text { owners/donated }\end{array}$ & 17 & 45 & 63 & 42 & 136 & 40 \\
\hline 2 & $\begin{array}{l}\text { Stray cattle brought by } \\
\text { Gaushala management }\end{array}$ & 13 & 37 & 50 & 33 & 116 & 34 \\
\hline 3 & $\begin{array}{c}\text { Purchased by } \\
\text { Gaushalamanagement }\end{array}$ & 7 & 18 & 37 & 25 & 88 & 26 \\
\hline & Total Inflow & 37 & 100 & 150 & 100 & 340 & 100 \\
\hline & & OUT & LOW OI & CATTLE & & & \\
\hline 1 & Died/Mortality & 1 & 4 & 4 & 6 & 8 & 8 \\
\hline 2 & Sold & 10 & 38 & 30 & 43 & 10 & 10 \\
\hline 3 & Donated & 15 & 58 & 35 & 51 & 80 & 82 \\
\hline & Total Outflow & 26 & 100 & 69 & 100 & 98 & 100 \\
\hline
\end{tabular}


Fig.1 Cattle herd dynamics in gaushalas

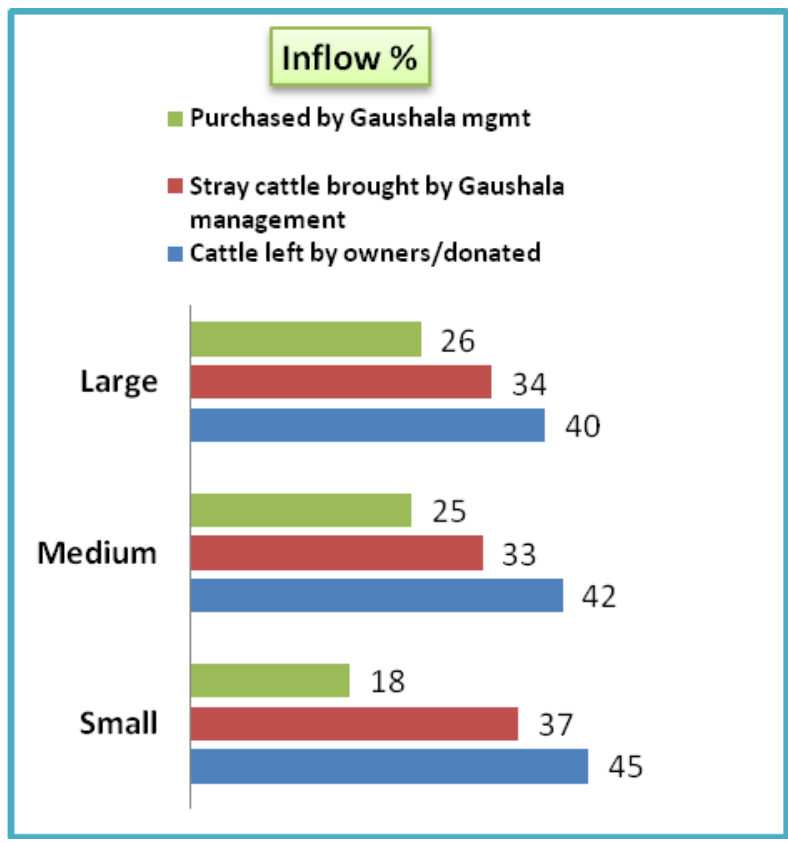

The outflow of cattle due to 'sale of cattle' in small, medium and large gaushalas was 38.00 percent, 43.00 percent and 10 percent, respectively. The outflow of cattle due to death or mortality of cattle in small, medium and large gaushalas was found to be 4.00 percent, 6.00 percent and 8.00 percent, respectively.

It could be inferred from the above results that majority of the inflow of cattle was due to 'cattle either abandoned or donated by the farmer to the gaushalas' which were mostly unproductive or old cattle were generally discarded from the farm and donated to the gaushalas. Very few gaushalas purchased cattle with good genetic traits, while, in the case of outflow, majority of cattle like heifers and male calves were donated to the neighboring genuine farmers. A few progressive gaushalas also sold cattle and very less outflow due to mortality was observed in all the three gaushalas. Therefore, the total inflow and outflow of cattle in gaushalas per annum was found to be 527 and 193 nos. of cattle respectively. Yadav and Vij (2011)

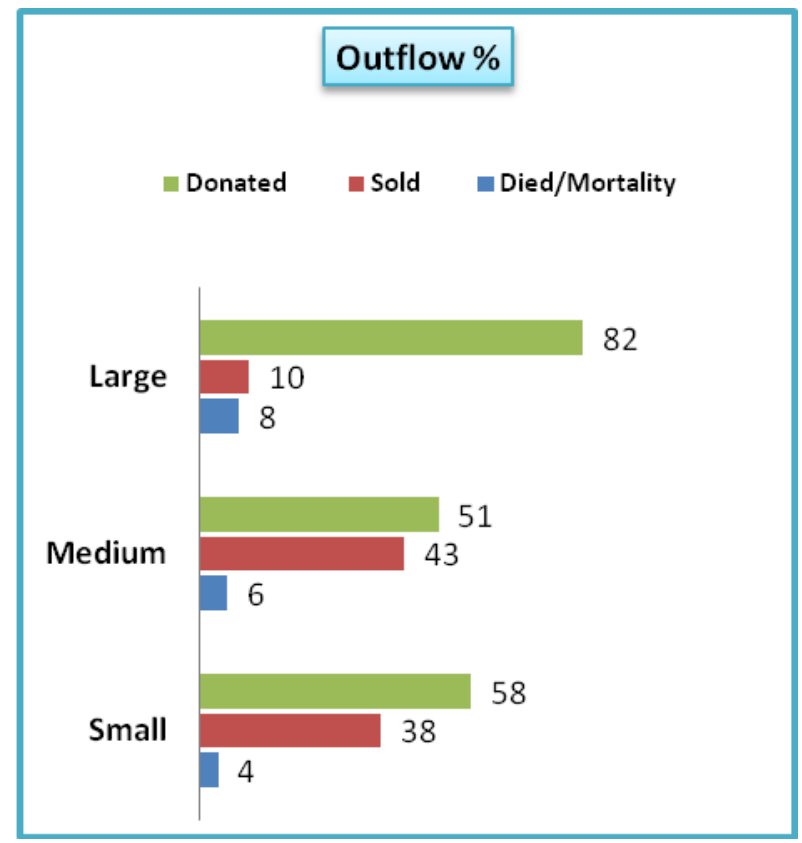

revealed similar results that on gaushalas located in Haryana State, among 101 gaushalas and found that total inflow and outflow of cattle in gaushalas per annum was 245 and 168 respectively.

Cattle herd dynamics in gaushalas play an important role in effective management of gaushalas. Due to erratic and continuous movement of animal herd in gaushalas i.e. inflow and outflow, it becomes challenge on the part of gaushala management to properly monitor and keep proper record of the cattle individually. It also helps to understand the herd composition and structure in the gaushalas which enables proper management of feeding, breeding and healthcare activities in gaushalas. The major reason for inflow of animals in gaushalas were; abandonment of cattle by farmer owners or donated as charity, stray cattle brought and purchase of good breeds of cattle by gaushala managers. However, death or mortality, sale of cattle and donation of young heifers and calves to the local farmers were the main reasons for outflow of cattle in gaushalas. The study will 
thus be helpful in taking decisions on management aspects, breeding policy, buying and selling strategies. It will also be very helpful in formulating improvement and conservation strategies of cattle genetic resources in gaushalas.

\section{Acknowledgement}

Authors are thankful to the ICAR-NDRI for providing financial assistance in terms of institutional fellowship and also thankful to Director, ICAR-NDRI, Karnal, and Head, SRS-ICAR-NDRI, Bengaluru for providing the necessary facilities for carrying out the research work.

\section{References}

$19^{\text {th }}$ Livestock Census.(2012). Department of Animal Husbandry, Dairying \& Fisheries, Ministry of Agriculture. Retrieved from http://www.dahd.nic.in/documents/stat istics/livestock-census on 13/06/18.

Agyemang, K., R. H. Dwinger, and A. S. Grieve. (1991). Milk Production Characteristics and of Productivity of Ndama Cattle under village management in the Gambia. Journal Dairy Sciences, 74:1599-1608.

Kumar, R., Singh, Satbir, Malik, P.K. and Prakash, B. (2009). Conservation of Hariana cattle through Gaushala - a refreshing experience. Journal of Livestock Biodiversity. Vol. 1 (2).

Little, D.A., G. J. Wassink and K. Agyemang.
(1994). Feed supplementation of lactating Ndama cows under village husbandry. Tropical Agriculture, 71: 223-228.

Sissokho, M. M. (1998). Cattle herd dynamics and performance under village husbandry in the Kolda region (Southern Senegal) (Doctoral dissertation).

Wilson, R. T. (1983). Recherchessur les Systemes des Zones Aridesdu Mali: Resultats Preliminaires. Rapport de Recherche CIPEA, 48:1-23.

Wilson, R. T. (1986). Livestock Production in Central Mali, long term studies on cattle and in the agropastoral system. ILCA Research Report, 14:43-63, Addis Abeba, Ethiopia.

Yadav, D. K. (2007). Ethno-veterinary practices: A boon for improving indigenous cattle productivity in Gaushalas. Livest. Res. Rural Dev, 19, $1-5$.

Yadav, D. K. and Vij, P. K. (2011).Cattle Herd Structure and Herd Dynamics in Gaushalas of Haryana. Journal of Livestock Biodiversity. Vol. 1(2).

Yadav, D.K. (2009). Gaushala System in India: Redefining its Utility? Livestock International. 13: 14-16.

Yadav, D.K. and Vij, P.K. (2010). Inventorization of Gaushala resources and their use in breed improvement and conservation programmes. Indian Journal of Animal Sciences, 80(4): 343-345, April 2010.

\section{How to cite this article:}

Kalyan Mandi, S. Subash, Subrata Koloi and Narendra Pratap Singh. 2019. Cattle Herd Dynamics of Gaushalas (Cow-shelter) in Karnataka State. Int.J.Curr.Microbiol.App.Sci. 8(12): 766-771. doi: https://doi.org/10.20546/ijcmas.2019.812.100 